\title{
Soros money filters through
}

Moscow. Scientists in the former Soviet Union (FSU) this month began to collect survival cheques from the $\$ 100$ millionfund set up last year by the US philanthropist George Soros. But doubts persist about whether the next and main round of research grants will be as successful in finding and funding the right scientists. Many are also sceptical about whether the money will make any long-lasting difference.

In this first phase, Soros's International Science Foundation (ISF, see Nature $\mathbf{3 6 0}$, $617 ; 1992)$ is distributing grants of $\$ 500$ to up to 20,000 individuals who have published at least three papers in recognized journals over the past five years (see Nature 362, 95; 1993). Applicants with good citation records receive a further payment of up to $\$ 1,000$ to help keep their research team intact.

ISF has overcome early concerns that it might be impossible to get the money to scientists, given that the FSU lacks a reliable banking system, and the alternative of wiring money directly to researchers was too expensive. It has paid researchers in US traveller's cheques, which they convert into cash at Moscow's Menatep commercial bank.

Officials at ISF's office in Moscow are also confident that the money went to the right people. But statisticians may raise an eyebrow at their survey method: "we became convinced of this by looking at the people who came to pick up the cheques."

\section{Lab practice helps poor kids}

Washington. A long-running scheme that lets US high-school students from poor families work in research laboratories during the summer has been an overwhelming success, the $\left(\frac{1}{2}\right.$ American Chemical Society (ACS) annual meeting in Chicago was told this week

More than three-quarters of the students surveyed in the city of Indianapolis who participated

in the ACS's

\section{Theodore Goodson}

Summer Educational Experience for the Disadvantaged (SEED) scheme went on to obtain college degrees, according to Ted Goodson, a research manager at Eli Lilly.

Goodson's retrospective study of the scheme's track record over 20 years in Indianapolis "proves the sceptics wrong", he says. A symposium and luncheon at the Chicago meeting will celebrate 25 years of the scheme's operation during which around 4,000 teenagers from most states have spent
The rescue plan will now move to its second and main phase of handing out research grants. But controversy still surrounds how best to spend the $\$ 100$ million pledged by Soros, says Alex Goldfarb, who supervises ISF's Moscow office. Soros and many Russians believe it should be shared among the 25,000 or so researchers active in basic research. Others, particularly the US members on ISF's executive committee and advisory board, argue it should be used to ensure the survival of the best research groups. Unfortunately, $\$ 100$ million is not enough to do both.

ISF has reached a compromise for the next round. Besides awarding grants, of up to $\$ 100,000$, to support large research projects, it will also make available some smaller grants to help research groups in danger of disappearing.

But Russia's top scientists may prefer to emigrate than face the "humiliation" of accepting the $\$ 350$ maximum monthly salary on offer, warns Maxim Frank-Kamenetskii of the Institute of Molecular Genetics in Moscow: "It would have been acceptable a year ago," he says, "but the purchasing power of the dollar is plummeting, and prices of basic goods are approaching those on the world market. Such terms deprive serious scientists of their last hope of working productively in their own country."

Getting grant applications peer-reviewed

8 to 10 weeks working as research assistants.

When ACS launched the scheme after the riots that followed the assassination of Martin Luther King in 1968, few believed it would succeed, says Goodson: "School teachers were reluctant. They thought the laboratories would be too sophisticated an environment for the kids. The researchers were high-minded, as you would expect, and the corporations thought the scheme was too optimistic." But they now enthusiastically support it, he says.

But nationally, where ACS administers the programme while seeking external support to pay the stipends of $\$ 1,200$ per student, the scheme is struggling to attract enough money to maintain last year's peak throughput of 300 students.

And if SEED's founders hoped to adjust the social and racial balance of American chemistry, a visit to Chicago will merely confirm that US science falls far short of "looking like America", to use President Clinton's celebrated phrase. "There's a long, long way to go", concedes Christine Brennan of ACS. "But we've helped a lot of students to gain the confidence to continue education beyond high school." Colin Macilwain by Western scientists is another problem facing the second round. Unlike large research foundations in the West, ISF does not have the resources to maintain an active network of referees. It intends to send applications to potential referees without notice, and is concerned that few may reply.

But the major question is whether Soros's $\$ 100$ million can make any permanent difference given the difficult economic situation in the FSU. It needs to run for five years, not one, if it is really to help, says Goldfarb: "We have saved a person from drowning by the hair, and are holding his head above water. But we will soon drop him, and swim ashore empty-handed." Soros's call for others to join the ISF programme has gone unheeded.

Vladimir Pokrovsky

\section{Israelis propose building tokamak in Russia}

Jerusalem. Israel is studying a proposal to order from Russia a small-aspect ratio tokamak as part of a joint fusion research programme.

Michael Finkenthal of Hebrew University and Dr Moshe Rosenblum of the Israeli Atomic Energy Commission presented the plan to Israel's new energy minister, Moshe Shalal, earlier this month. The Ministry of Energy is "actively considering" the proposal, says its chief scientist Amnon Einav.

The scientists advise against buying an existing Russian tokamak as proposed by Russia earlier this year. Instead, they recommend that Israel adapt the small-aspect ratio tokamak design developed at the Yoffe Institute in St Petersburg. They say it has advantages over the conventional tokamak and could be adapted for research into the important area of steady-state operation. Under the joint programme, a similar device would be built for Russian researchers. Constructing a small tokamak in Russia could cut construction costs to US\$5-\$10 million, say Israeli scientists.

E. P. Velikhov of the Russian Academy of Science proposed the joint venture to the Israeli prime minister, Yitzhak Rabin, earlier this year. He suggested it could give Israel a stepping-stone to the International Thermonuclear Reactor Programme: Russia takes part in the programme - along with the United States, Europe and Japan - and can invite other countries to join its efforts.

Prospects for a national fusion programme in Israel have been improved by the arrival of immigrant fusion scientists from the former Soviet Union. "Before, we lacked a critical mass of scientists with hands-on experience" says Finkenthal. Eleven such immigrants have now been told that they may yet find work in their field - something most of them had given up on.

Abraham Rabinovich 